\title{
Correction to: Study protocol: baby-OSCAR Trial: Outcome after Selective early treatment for Closure of patent ductus ARteriosus in preterm babies, a multicentre, masked, randomised placebo-controlled parallel group trial
}

Samir Gupta ${ }^{1 *}$, Edmund Juszczak ${ }^{2,3}$, Pollyanna Hardy ${ }^{2,4}$, Nimish Subhedar ${ }^{5}$, Jonathan Wyllie ${ }^{6}$, Wilf Kelsall? Sunil Sinha ${ }^{6}$, Sam Johnson ${ }^{8}$, Tracy Roberts ${ }^{4}$, Elisabeth Hutchison ${ }^{2}$, Justine Pepperell ${ }^{2}$, Louise Linsell ${ }^{2}$, Jennifer L. Bell ${ }^{2}$, Kayleigh Stanbury' ${ }^{2}$, Marketa Laube ${ }^{2}$, Clare Edwards², David Field ${ }^{8}$ and on behalf of the 'The Baby-OSCAR Collaborative Group'

\section{Correction to: BMC Pediatr 21, 100 (2021) https://doi.org/10.1186/s12887-021-02558-7}

Following the publication of the original article [1], it came to the authors' attention that some text in the Open Label Treatment section deviated from the original wording of the protocol described.

The wording used in the original protocol is:

To consider open label (Rescue) treatment, both clinical AND echocardiographic criteria as described below should be met:

1. Clinical findings of inability to wean on ventilator (ventilated for at least 7 days continuously) AND inability to wean oxygen

OR

Persistent hypotension and/or pulmonary haemorrhage and/or signs of cardiac failure

The original article can be found online at https://doi.org/10.1186/s12887021-02558-7

* Correspondence: samir.gupta@durham.ac.uk

'University Hospital of North Tees, Hardwick Road, Stockton-On-Tees TS19 8PE, UK

Full list of author information is available at the end of the article
2. Echocardiographic findings of a large PDA (PDA $\geq$ $2.0 \mathrm{~mm}$ with pulsatile flow)

AND

Hyperdynamic circulation and/or ductal steal (please refer to Baby-OSCAR ECHO workbook).

However, the section in question had used the following wording:

1. Inability to wean on ventilator (ventilated for at least 7 days continuously) and any of: inability to wean oxygen; persistent hypotension; pulmonary haemorrhage; signs of cardiac failure AND

2. Echocardiographic findings of a large PDA $(\geq 2.0$ $\mathrm{mm}$ with pulsatile flow)

AND

3. Echocardiographic findings of hyperdynamic circulation or ductal steal (refer to Baby-OSCAR ECHO workbook).

C The Author(s). 2021 Open Access This article is licensed under a Creative Commons Attribution 4.0 International License, which permits use, sharing, adaptation, distribution and reproduction in any medium or format, as long as you give appropriate credit to the original author(s) and the source, provide a link to the Creative Commons licence, and indicate if changes were made. The images or other third party material in this article are included in the article's Creative Commons licence, unless indicated otherwise in a credit line to the material. If material is not included in the article's Creative Commons licence and your intended use is not permitted by statutory regulation or exceeds the permitted use, you will need to obtain permission directly from the copyright holder. To view a copy of this licence, visit http://creativecommons.org/licenses/by/4.0/ The Creative Commons Public Domain Dedication waiver (http://creativecommons.org/publicdomain/zero/1.0/) applies to the data made available in this article, unless otherwise stated in a credit line to the data. 


\section{Author details}

${ }^{1}$ University Hospital of North Tees, Hardwick Road, Stockton-On-Tees TS19 8PE, UK. ${ }^{2}$ National Perinatal Epidemiology Unit (NPEU) Clinical Trials Unit, Nuffield Department of Population Health, University of Oxford, Old Road, Campus, Headington, Oxford OX3 7LF, UK. ${ }^{3}$ Nottingham Clinical Trials Unit, School of Medicine, University of Nottingham, University Park Nottingham, Nottingham NG7 2RD, UK. Institute of Applied Health Research, University of Birmingham, Birmingham B15 2TT, UK. ' Liverpool Women's NHS Foundation Trust, Crown Street, Liverpool L8 7SS, UK. 'South Tees Hospitals NHS

Foundation Trust, James Cook University Hospital, Middlesbrough TS4 3BW, UK. ${ }^{7} \mathrm{NICU}$, Rosie Hospital, Cambridge University Hospital Foundation Trust, Cambridge CB2 2QQ, UK. ${ }^{8}$ Department of Health Science, The University of Leicester, University Road, George Davies Centre, Leicester LE1 7RH, UK.

Published online: 27 July 2021

Reference

1. Gupta S, Juszczak E, Hardy P, et al. Study protocol: baby-OSCAR trial: Outcome after Selective early treatment for Closure of patent ductus ARteriosus in preterm babies, a multicentre, masked, randomised placebocontrolled parallel group trial. BMC Pediatr. 2021;21(1):100. https://doi.org/1 0.1186/s12887-021-02558-7. 